Лобко М. М., канд. військ. наук, доцент Фучко А. Й.

Центр воєнно-стратегічних досліджень Національного університету оборони України імені Івана Черняховського, Київ

\title{
Деякі аспекти розвитку форм і способів застосування Збройних Сил України для відсічі збройної агресії в сучасних умовах
}

Резюме. У статті розглянуто роль та вплив розвитку форм і способів застосування Збройних Сил України для відсічі збройної агресії в сучасних умовах на організаційну структуру Збройних Сил України та систему управління ними.

Ключові слова: доктрина; відсіч збройної агресії проти України; сили оборони; Збройні Сили України та інші складові сил оборони; об'єднані сили; операція Об'єднаних сил; операції угруповань військ (сил).

Постановка проблеми. Намагання влади України проводити політику щодо врегулювання збройного конфлікту на Донбасі мирним шляхом не знаходять розуміння та підтримки серед російського політичного істеблішменту. До того ж, кремлівське керівництво під приводом історичної несправедливості фактично висуває територіальні зазіхання на східні та південні території України. Загалом воєннополітична обстановка довкола нашої держави оцінюється як нестабільна, а загрози у військовій сфері є актуальними.

Відтак, перед воєнно-політичним керівництвом держави проблема збройного захисту національних інтересів залишається нагальною. Важливого значення у питанні збройного захисту держави набуває розвиток форм і способів застосування Збройних Сил (3С) України для відсічі збройної агресії в сучасних умовах. Проблема ускладнюється ще й тим, що сучасні воєнні конфлікти все більше набирають “гібридного” характеру.

Аналіз останніх досліджень та публікацій. На сьогодні зазначене питання досить жваво обговорюється як у фахових виданнях, так i в ЗМІ. Обговоренню зазначеної проблеми присвячені статті авторів [1-4].

Однак проведене вивчення публікацій 3 цієї проблеми показує, що висвітлені в них розвиток форм і способів застосування ЗС України для відсічі збройної агресії в сучасних умовах носять загальний, часто неконкретний $\mathrm{i}$ несистемний характер. В окремих 3 них не враховуються положення національного законодавства. Деякі автори не знайомі зі змістом керівних документів Міністерства оборони (МО) України i ЗС України з даного питання і не враховують ïx основні положення. Відтак, проблема розроблення і систематизація форм і способів застосування ЗС України для відсічі збройної агресії в сучасних умовах $\epsilon$ актуальною.

Метою статті є: на основі проведеного аналізу положень вітчизняного законодавства, керівних документів МО України, ЗС України, публікацій 3 цієї проблеми, досвіду проведення АТО, ООС на Сході нашої держави викласти погляди на розвиток форм $\mathrm{i}$ способів застосування ЗС України для відсічі збройної агресії в сучасних умовах.

Виклад основного матеріалу. У 2018 році Верховним Головнокомандувачем ЗС України затверджена Доктрина застосування сил оборони держави (далі Доктрина).

Зазначена Доктрина $\epsilon$ системою поглядів на роль, місце та завдання сил оборони держави, захисту іiі суверенітету, територіальної цілісності та недоторканності, a також на принципи i підходи до їх застосування під час виконання завдань із захисту держави в разі збройної агресії в будьяких iii формах і виявах, зокрема у формі "гібридної війни".

Проведене наукове дослідження показало, що Доктрина за своєю сутністю, теоретичними положеннями, змістом $\epsilon$ важливим кроком вперед на шляху подальшого розвитку воєнного мистецтва для забезпечення виконання завдань оборони держави силами оборони і їх найважливішою складовою - Збройними Силами України. Звісно, що воєнне мистецтво в умовах російської агресії потребує свого подальшого і постійного розвитку та вдосконалення. У Доктрині в основному надані форми і способи застосування ЗС України, їх особливості, 
притаманні для умов, що склались в Україні, у зв'язку зі збройною агресією РФ.

Водночас, Доктрина містить

положення, які суперечать певним нормам

вітчизняного законодавства, інших

нормативно-правових актів і теорії воєнного мистецтва.

Розглядаючи питання застосування сил оборони держави слід визначитись 3 поняттям “сили оборони".

Довідка. Згідно 3 п. 18 ст. 1 [5] - “сили оборони - Збройні Сили України, а також інші утворені відповідно до законів України військові формування, правоохоронні та розвідувальні органи, органи спеціального призначення 3 правоохоронними функціями, на які Конституцією i законами України покладено функиії із забезпечення оборони держави".

Відповідно до п. 4 розділу 1 [6] (у редакції 2015 року) “сили оборони - Збройні Сили України, Державна служба спеціального зв'язку та захисту інформації України, Державна спеціальна служба транспорту, інші утворені відповідно до законів України військові формування, а також правоохоронні та розвідувальні органи, в частині залучення їх до виконання завдань з оборони держави".

Як показує проведене дослідження у Доктрині цей термін (його друга частина) викладений неточно і некоректно. До того ж, друга частина дублює першу частину. У подальших положеннях Доктрини також некоректним $є$ розділення військових формувань, правоохоронних та розвідувальних органів на тих, що “беруть безпосередню участь або виконують допоміжну роль у виконанні завдань (проведення операцій) оборони держави”. Адже їх завдання встановлені законодавством України, у якому не передбачається таке розділення. До того ж, під час проведення операцій вони відіграють головну роль (тобто, “беруть безпосередню участь”) у виконанні покладених на них завдань (наприклад, боротьба 3 тероризмом (Служба безпеки України), ліквідація надзвичайних ситуацій у районі бойових дій (Державна служба України 3 надзвичайних ситуацій) тощо) за участі (тобто, виконують так звану “допоміжну роль”) військових частин, підрозділів, органів Збройних Сил України, інших військових формувань, правоохоронних та інших державних органів.

Довідка. У другому абзаці п. 1 Доктрини встановлено, що "У Доктрині під силами оборони розуміються сили і засоби Збройних Сил України, ДССТ, інших утворених відповідно до законів України військових формувань, правоохоронних i розвідувальних органів у частині залучення їх до виконання завдань оборони держави, а також інших складових сил безпеки, які в порядку і на умовах, що визначені законодавством України, залучаються (беруть безпосередню участь або виконують допоміжну роль) до виконання завдань (проведення операцій) оборони держави."

Отож доцільно керуватись визначенням наведеним у [6].

Варто визначитись зі складом сил оборони. До складу сил оборони входять органи військового управління, з'єднання, військові частини видів, родів, спеціальних військ (сил), логістики ЗС України, а також визначені Генеральним штабом ЗС України, за погодженням 3 відповідними керівниками державних органів, органи військового управління, військові частини, підрозділи, органи зі складу інших військових формувань, правоохоронних і розвідувальних органів, які виконують покладені на них законодавством завдання за планами операцій командувачів об'єднаних сил у встановлених операційних зонах (районах, смугах). До таких завдань слід віднести: боротьба 3 тероризмом, розвідувально-диверсійними силами противника, НЗФ; виконання заходів правового режиму воєнного стану; забезпечення діяльності місцевих органів державної влади та підтримання правопорядку; охорона (оборона) важливих об'єктів державної і військової інфраструктури, зокрема шляхів і доріг, що використовуються військами; боротьба 3 бандитизмом, мародерством, грабіжництвом, торгівлею зброєю, наркотиками тощо.

Ще за мирного часу (під час підготовки операцій) зазначені органи військового управління, з'єднання, військові частини, підрозділи, органи зі складу сил оборони мають здійснювати спільну підготовку до виконання завдань за планами операцій об'єднаних сил.

Також необхідно визначитись 3 такими термінами як “застосування сил оборони”, “система застосування сил оборони”, “операція сил оборони” та співвідношення між ними.

У розділі 1 згаданої Доктрини наводиться термін "застосування сил оборони" і розглядається як “установлений порядок дій сил оборони щодо виконання завдань у мирний час та в особливий період (воєнний час) для досягнення визначеної для них воєнно-політичної (воєнно-стратегічної) мети".

По-перше, щодо “установленого порядку дій сил оборони”, то розуміється 
визначена цілеспрямована послідовність дій 3 виконання покладених завдань, зокрема 3 оборони держави. Якщо послідовність дій (установлений порядок дій) здійснюється цілеспрямовано то вона має проводитись у встановлених формах застосування, що $\epsilon$ характерним для формувань, які виконують покладені на них законодавством завдання із застосуванням зброї або сили, якими є сили оборони.

По-друге, щодо "виконання завдань" (яких завдань?), то 3 наведених визначень видно, що на сили оборони покладається виконання завдань “з оборони держави” або “забезпечення оборони держави”, про що й необхідно конкретно вказати.

По-третє, щодо “досягнення визначеної для них воєнно-політичної (воєнностратегічної) мети”. Слід мати на увазі, що, як писав К. Клаузевіц, воєнно-політичну мету воєнного конфлікту визначає вище воєннополітичне керівництво держави. Воєннополітична мета має бути направленою проти держави противника i досягається проведенням комплексу політичних (зокрема, внутрішніх), дипломатичних, економічних, інформаційних, пропагандистських, воєнних, спеціальних та інших заходів. Їі результатом може бути “виведення держави 3 війни”, “примушення до припинення збройної агресії проти іншої держави” (або примушення до миру) та інші.

Для збройних сил визначається воєнностратегічна мета зважаючи на визначену воєнно-політичну мету. Вона має полягати у розгромі збройних сил противника, оволодіння певними територіями (важливими об'єктами) і забезпеченні досягнення воєннополітичної мети.

По-четверте, “щодо виконання завдань у мирний час". Відповідно до вітчизняного законодавства, термін "застосування" (зокрема, 3С України, які складають основу сил оборони) стосується відсічі збройної агресї проти Украӥни, що встановлено законом.

Згідно зі ст. 4 [6] "У разі збройної агресії проти України або загрози нападу на Україну Президент України приймає рішення про загальну або часткову мобілізацію, введення воєнного стану в Україні або окремих ii місцевостях, застосування Збройних Сил України, інших військових формувань, утворених відповідно до законів України, подає його Верховній Раді України на схвалення чи затвердження, а також вносить до Верховної Ради України подання про оголошення стану війни" [7]. Тобто, згідно 3 положенням законодавства, не може йтися про відсіч збройної агресї проти Украӥни за мирного часу, оскільки має проводитись мобілізація i уводитись правовий режим воєнного стану за результатами чого наступає особливий період, складовою якого є воєнний час.

Варто також зазначити, що крім оборони України на ЗС України покладається виконання й інших завдань [8].

Довідка. Згідно зі ст. 1 [5] на ЗС України покладається таке: “3'єднання, військові частини $i$ nідрозділи Збройних Сил України відповідно до закону можуть залучатися до здійснення заходів правового режиму воєнного і надзвичайного стану, організації та підтримання дій руху опору, проведення військових інформаційно-психологічних операцій, боротьби 3 тероризмом і піратством, заходів щодо здійснення захисту життя, здоров'я громадян та об'єктів (майна) державної власності за межами України, забезпечення їх безпеки та евакуації (повернення), посилення охорони державного кордону, захисту суверенних прав України у її виключній (морській) економічній зоні та на континентальному шельфі та їх правового оформлення, забезпечення безпеки національного морського судноплавства України у відкритому морі чи в будь-якому місці поза межами юрисдикції будь-якої держави, заходів щодо запобігання розповсюдженню зброї масового ураження, протидії незаконним перевезенням зброї i наркотичних засобів, психотропних речовин, їх аналогів або прекурсорів у відкритому морі, ліквідації надзвичайних ситуацій природного і техногенного характеру, надання військової допомоги іншим державам, а також брати участь у міжнародному військовому співробітництві, міжнародних антитерористичних, антипіратських та інших міжнародних операціях 3 підтримання миру і безпеки на підставі міжнародних договорів України та в порядку і на умовах, визначених законодавством України".

На сьогодні на сході України проводиться операція Об'єднаних сил (ООС).

OOC проводиться в особливих умовах, що склались в Україні за результатами збройної агресії РФ “гібридного” типу та дії Мінських угод, які серед іншого, обмежують застосування зброї i військової техніки, а також інших факторів i тому має свої особливості. Для проведення зазначеної операції визначені правовий режим та особливий порядок забезпечення прав і свобод цивільного населення у межах тимчасово окупованих територій у Донецькій та Луганській областях, які встановлені законами України [9], [13] та іншими.

ООС проводитиметься до завершення виконання завдань щодо звільнення 
окупованих територій у Донецькій i Луганській областях і відновлення конституційного ладу на них як в умовах мирного часу, так і в особливий період (як це було у листопаді-грудні 2018 року) у разі загрози або спроби розширення збройної агресії РФ у цих областях.

Іиформація. Проблема полягає в тому, що Російською Федерацією здійснена збройна агресія проти України із застосуванням методів і способів, які дістали назву "гібридних" (у ЗМІ використовується термін "гібридна війна").

Гібридні методи і способи збройної агресії у таких масштабах Росією використались уперше у світовій практиці.

У війнах і збройних конфліктах минулого основу збройної агресії складали воєнні дії, які визначали іiі сутність і зміст та вирішували основні завдання у здобутті воєнної перемоги i забезпеченні досягнення воєнно-політичних цілей. Політичні, дипломатичні, економічні, соціальні, інформаційні, пропагандистські заходи проводились політичним керівництвом держави агресора для створення першочергово вигідних політичних умов застосування воєнної сили i відігравали допоміжну роль у цьому.

У сучасних умовах глобалізованого світу, бурхливого розвитку комунікацій, інформаційних технологій тощо, з'явились нові спроможності у вирішенні суперечок між державами та реалізації власних національних інтересів. Це надає можливості здійсненню збройної агресії 3 використанням комплексних (“гібридних") методів i механізмів, пріоритетом у яких $\epsilon$ політичні, дипломатичні, економічні, соціальні, інформаційні, пропагандистські, спеціальні заходи, а воєнні засоби використовуються для їх силової підтримки.

Отже, існуюча система міжнародної безпеки, іiі безпекові інститути (ООН, ОБСЄ та ін.) виявились не готовими до протидії агресивним діям Росії в 2014 році та у подальші роки, а розроблені у другій половині $\mathrm{XX}$ століття документи (Статут ООН, міжнародні угоди, конвенції тощо) не відповідають новим умовам, що склались і не забезпечують повною мірою дієвого впливу задля підтримання миру і безпеки у світі.

$\mathrm{He}$ підготовленою належним чином виявилась і наша держава. Цим і пояснюються особливості протидії України збройній агресії РФ, закрема і шляхом проведення АТО і ООС.

У Доктрині встановлено, що “сукупність узгоджених та взаємозв'язаних форм застосування сил оборони, спрямованих на досягнення воєнно-політичних цілей воєнного конфлікту шляхом вирішення всього комплексу стратегічних i оперативних завдань, становить систему застосування сил оборони".
Зазначена система застосування сил оборони включає: стратегічні дії (стратегічне розгортання сил оборони, ППО України, територіальну оборону України, рух опору, операцію сил оборони); операцію сил оборони (OOC) - на основному напрямку, операції військ (сил) угруповань військ (сил, органів) - на інших напрямках, інші операціï (повітряна, морська, спеціальна,інформаційна, психологічна, кібернетична).

Слід зазначити, що і стратегічні дії, i операція сил оборони, інші операції, проводяться силами оборони у встановленій системі застосування цих сил оборони. Однак у Доктрині до стратегічних дій віднесено операцію сил оборони. Тобто, сили оборони застосовуються у встановленій системі застосування сил оборони, але вони мають проводити свою операцію (операцію сил оборони), яка не охоплює визначену систему їх застосування.

Як зазначено у Доктрині до операщії сил оборони входять: ООС (на основному напрямку); операції військ (сил) угруповань військ (сил, органів) на інших напрямках; інші операції.

Натомість, виходить, що інші види стратегічних дій (див. вище) не є складовою операції сил оборони і проводяться не силами оборони, хоча йдеться про систему застосування саме сил оборони.

Необхідно зазначити, що і “операція сил оборони" i "застосування сил оборони" проводяться для відбиття збройної агресії проти України шляхом виконання визначених “стратегічних, оперативних (оперативнотактичних) завдань”. Ці завдання однакові для сил оборони, що під час їх застосування, що у їх операції, тобто, відсіч збройної агресії.

Отже, у термінах “застосування сил оборони” і “операція сил оборони” присутня певна суперечливість. Проведений аналіз, дозволив констатувати, що ці терміни мають однакові характерні риси, сутність та зміст і їх необхідно об'єднати та встановити як “застосування Збройних Сил Украӥни та інших складових сил оборони". ЗС України та інші складові сил оборони для відсічі збройної агресії мають застосовуватись у відповідних формах, тобто, у визначеній системі застосування.

Відтак, доцільним буде й змінити назву існуючої Доктрини на “Доктрина застосування Збройних Сил Украӥни та інших складових сил оборони".

Інформація. Законодавством України не встановлено, що керівництво силами оборони 
здійснює Президент України як Верховний Головнокомандувач 3С України. Таке положення суперечитиме ст. 17 - “Оборона України, захист іiі суверенітету, територіальної цілісності i недоторканності покладаються на Збройні Сили України” та П. 17 ст. 106 - [Президент України] “ $\epsilon$ Верховним Головнокомандувачем Збройних Сил України"(а не сил оборони)[10].

До того ж, сили оборони є формуванням, що утворюється за функціональною ознакою і не має постійного складу i необхідної організаційної структури.

Окрім цього, до складу сил оборони входять органи, військові частини, підрозділи інших міністерств, відомств, які відповідно до законодавства, не підпорядковуються Президентові України.

Оскільки Україна, як і їі Збройні Сили не могли проводити стратегічні операції (за рішенням політичного керівництва держави Україна відмовилась від ядерних озброєнь, стратегічної звичайної зброї, не мала угруповань військ (сил) стратегічного масштабу, необхідних ресурсів для їх забезпечення), то керівництвом Міністерства оборони, Генерального штабу 3С України у середині 90-х років було прийнято рішення відмовитись від термінів “стратегічна операція”, “стратегічна операція Збройних Сил України”, “стратегічна операція на стратегічному напрямі” тощо, які $\epsilon$ непритаманними для них та вживати термін “застосування Збройних Сил Украӥни”. Під цим терміном розуміється встановлений порядок дій військ (сил) ЗС України у визначених формах застосування з виконання покладених законодавством завдань оборони держави.

За такого підходу термін “застосування Збройних Сил України” відноситься до стратегічного масштабу.

Для виконання покладених законодавством завдань оборони держави зі складу 3С України, інших військових формувань, правоохоронних, розвідувальних органів, інших державних органів, що залучаються до виконання цих завдань, визначаються відповідні органи військового управління, з'єднання, військові частини, органи, підрозділи 3 яких формуються необхідні угруповання військ (сил) за відповідними напрямами дій. Ще за умов мирного часу визначені Генеральним штабом 3С України органи військового управління, з'єднання, військові частини, органи, підрозділи С України, інших військових формувань, правоохоронних, розвідувальних органів, інших державних органів складають сили оборони.

За умов здійснення збройної агресії із використанням гібридних методів і способів, угруповання військ (сил) на різних напрямах мають бути об'сднаними силами. Основу визначених угруповань військ (сил) мають складати оперативні об 'сднання (оперативнотактичні з'єднання) як військові формування, на які покладається основний тягар i відповідальність за виконання завдань в операціях (бойових діях) i на основі яких мають формуватись відповідні угруповання військ (сил) як об’єднані сили.

У разі загрози чи здійснення збройної агресії проти України, рішення на застосування 3С України, інших військових формувань приймає Президент України, Верховний Головнокомандувач 3С України (ст. 106 [10] та ст. 4 [7]). Він і встановлюе порядок дій військ (сил), визначає форми застосування 3 виконання покладених законодавством завдань оборони держави (відповідно до визначеної системи застосування 3С України та інших складових сил оборони), організацію управління, забезпечення й інші питання за пропозицією Генерального штабу ЗС України.

Операція 3С України, операція сил оборони за масштабом, іншими показниками, також мають бути стратегічного масштабу. У такому разі термін "застосування Збройних Сил України” має відноситись до "надстратегічного” масштабу, що є алогічним. До того ж, збройні сили $є$ військовим формуванням (у деяких державах $є$ воєнною організацією, яка включає крім збройних сил й інші військові формування) і не проводять операцію. Воєнна історія таких прикладів не знає.

Ось чому, визначення “операція збройних сил”, “операція сил оборони” $\epsilon$ збірними термінами i мають вживатись у загальному значенні.

Терміни “операції збройних сил”, “операції сил оборони” слід розуміти i вживати як операції, що проводяться об'єднаннями, з'єднаннями (утвореними угрупованнями) збройних сил зі складу сил оборони відповідно до визначеної системи їх застосування.

Довідка. Застосування (застосовувати) - дія зі значенням використовувати що-небудь для чогось [11].

Стратегічне керівництво ЗС України здійснює Президент України як Верховний Головнокомандувач ЗС України. Начальник 
Генерального штабу - Головнокомандувач Збройними Силами України (у перспективі Головнокомандувач Збройними Силами України) здійснює безпосереднє військове керівництво ними.

Довідка. Згідно зі ст. 8 [8] - “безпосередне військове керівництво - діяльність, спрямована на здійснення заходів щодо розвитку Збройних Сил України, їх технічного оснащення, підготовки та всебічного забезпечення, визначення основ їх застосування, а також управління ними".

Відтак, безпосереднє військове керівництво ЗС України відноситься до стратегічного рівня.

Щодо операції сил оборони. У Доктрині визначено, що операчія сил оборони є сукупністю узгоджених і взаємозв'язаних за метою, завданнями, місцем i часом одночасних або послідовних операцій: об'єднаних сил (на основному напрямку); угруповань військ (сил, органів) (на інших напрямках); повітряної, морської, спеціальної; інформаційної; психологічної, кібернетичної, які проводяться для виконання визначених стратегічних, оперативних (оперативнотактичних) завдань в операційних зонах (районах, смугах) в установлений період під єдиним керівництвом".

Надалі зазначається, що за своїм змістом операція об'єднаних сил та операції угруповань військ (сил, органів) поділяються на: оборонні, наступальні (контрнаступальні), 3 виведення військ (сил, органів) 3-під ударів противника, стабілізаційні.

Наведені положення Доктрини суперечать нормам викладеним у Законах України "Про національну безпеку України" [5] та "Про особливості державної політики із забезпечення державного суверенітету України на тимчасово окупованих територіях у Донецькій та Луганській областях" [9].

3 огляду на положення національного законодавства, що визначає особливості державної політики із забезпечення державного суверенітету України на тимчасово окупованих територіях у Донецькій та Луганській областях, враховуючи особливості умов виконання покладних завдань за встановленим правовим режимом та особливим порядком забезпечення прав i свобод цивільного населення у межах тимчасово окупованих територій у Донецькій та Луганській областях, “операція Об'єднаних сил” є особливою формою застосування військ (сил) зі складу сил оборони i становить собою "комплекс скоординованих за метою, завданнями, місцем i часом військових, спеціальних, організаційно-правових, інших заходів (дій), що проводяться за єдиним замислом і планом спрямованих на забезпечення національної безпеки і оборони на тимчасово окупованих територіях".

ООС проводиться на територіях Донецької та Луганської областей з метою “забезпечення військової підтримки 3 реалізації державної політики із звільнення, відновлення конституційного ладу й державного суверенітету України на тимчасово окупованих територіях у Донецькій та Луганській областях, підтримання встановленого вітчизняним законодавством правового режиму (особливого порядку) щодо забезпечення прав і свобод цивільного населення на цих територіях".

Відповідно до зазначеної мети визначено і відповідні оперативні завдання.

Необхідно акцентувати, що саме у разі розширення збройної агресії Російської Федерації за межі Донецької та Луганської областей Об'єднані сили готуватимуть і проводитимуть визначені Доктриною оборонні, наступальні (контрнаступальні), стабілізаційні та інші операції. Однак ці операчії не мають бути складовою та змістом OOC, адже вона проводиться із завданням забезпечення національної безпеки і оборони на територіях Донецької та Луганської областей. Під час виконання цього завдання у Донецькій та Луганській областях на сьогодні Об'єднані сили не проводять визначені Доктриною оборонні, наступальні (контрнаступальні), стабілізаційні та інші операції, а проводять військові, спеціальні, організаційно-правові, інші заходи (діï).

Звісно, що за своєю сутністю, метою, завданнями і змістом ООС (у Донецькій та Луганській областях) не може поділятись на оборонні, наступальні (контрнаступальні), 3 виведення військ (сил, органів) 3-під ударів противника, стабілізаційні операції тощо.

Отже, ООС проводитиметься в особливих умовах на територіях Донецької та Луганської областей до їx звільнення i відновлення конституційного ладу. Тому ООС має бути у системі застосування сил оборони як особлива форма їх застосування, яка проводиться як протидія збройній агресії РФ гібридного типу на Донбасі.

Щодо розділення операції сил оборони на операції об'єднаних сил (на основному напрямку) та угруповань військ (сил, органів) (на інших напрямках).

Відповідно до п. 6 ст. 16 [5] встановлено, що "Президент України може 
призначати командувача (командувачів) об'єднаних сил для здійснення управління операціями на окремих напрямках".

Отже, розділення операції сил оборони на операцію Об'єднаних сил на основному напрямку та операції угруповань військ (сил) на інших напрямках суперечить положенню наведеного закону України.

Крім того, сучасні воєнні конфлікти носять комплексний (“гібридний”) характер. Тому відсіч збройної агресії на різних напрямках ударів оперативно-стратегічних (оперативних) об'єднань противника мають здійснювати угруповання об'єднаних сил як на основному напрямку, так і на інших.

Звідси випливає, що у разі розширення збройної агресії Російської Федерації за межі Автономної Республіки Крим та міста Севастополя (ст. 10) [9] іï відсіч має здійснювати ОК "Південь” відповідно до встановленої [12] військово-сухопутної зони відповідальності для оперативного командування "Південь", як оперативне об'єднання (оперативно-тактичне 3'єднання) 3С України, а відтак і сил оборони. До складу цього об'єднання (з'єднання) мають увійти органи військового управління, 3'єднання, військові частини видів, родів, спеціальних військ (сил) ЗС України, органи, військові частини і підрозділи інших військових формувань, правоохоронних і розвідувальних органів зі складу сил оборони, інших державних органів, які залучаються до виконання завдань оборонної операції ОК “Південь” на кримському напрямі.

Отже, за складом, сутністю, метою, завданнями і змістом це об'єднання (з'єднання) буде об'єднаними силами. Однак для виконання покладених завдань ОК "Південь", на відміну від ООС у Донецькій і Луганській областях, готуватиме i проводитиме оборонні, контрнаступальні й інші операції.

Викликає сумнів щодо доцільності встановлення Доктриною однією 3 форм стратегічних дій “рух опору”.

По-перше, на рух опору зазначеним документом не покладається виконання стратегічних чи навіть оперативних завдань.

По-друге, для виконання таких завдань мають бути утворені відповідного масштабу формування руху опору, що в сучасних умовах $\epsilon$ проблемою.

Звідси, по-третє, у наших умовах масштаб дій формувань руху опору не мають стратегічного чи оперативного рівня (на кшталт формувань УПА в Західній Україні, армії Людової та армії Крайової в Польщі, чи партизанських з'єднань Ковпака, Сабурова, Медвєдєва на території України у роки Другої світової війни). Сили руху опору можуть, як вбачається, виконувати лише тактичні завдання групами, дрібними підрозділами та можливо лише за певних умов кількома підрозділами в рамках операції, наприклад, об'єднаних сил. Отже, переведення руху опору на стратегічний рівень є надмірним про що свідчить п'ятирічний досвід організації руху опору на окупованій частині території Донбасу та Криму.

Територія України омивається Чорним i Азовським морями. На сьогодні це гостро ставить питання оборони морського узбережжя, що підтверджується агресивними діями РФ у районі Керченської протоки і Азовського моря. Однак форми застосування військ (сил) для оборони морського узбережжя в системі застосування сил оборони держави Доктриною не визначено.

Замість цього в оборонній операції на приморському напрямку передбачено утворення “системи оборони морського узбережжя", зокрема системи протидесантної оборони.

Зазначається, що система оборони морського узбережжя включає: протидесантну оборону доступних для висадки ділянок узбережжя, пунктів базування ВМС ЗС України, портів та інших об'єктів, протиповітряну, протикорабельну (протикатерну) оборону, протичовнове, протимінне та протипідводнодиверсійне забезпечення, мінно-загороджувальні та протимінні дії в морській зоні, установлення мінних загороджень у прибережній зоні та на березі.

Як показало проведене дослідження у наведених термінах присутня певна колізія. Не вдаючись до детальних теоретичних положень слід зазначити, що у теорії воєнного мистецтва на сьогодні 3 цього питання існує чотири основні наукові категорії.

Категорія перша: оборона морського узбережжя - це різновид оборони, як і оборона в горах, у пустелі тощо (тобто, в особливих (відмінних) умовах). Для ऑiі здійснення утворюється об'єднання до складу якого включаються з'єднання, військові частини видів 3С України (CB, ПС, ВМС), родів ЗС України та інших складових сил оборони. Метою утвореного угруповання військ (сил) $є$ відбиття ударів та недопущення вторгнення противника на територію держави з моря.

Оборона морського узбережжя може проводитись у формі операції або бойових дій.

Варто особливо підкреслити, що форми застосування військ (сил) для оборони морського узбережжя за сутністю, метою, завданнями і змістом суттєво різняться від оборони на суходолі.

Категорія друга: протидесантна оборона - це складова оборонної операції об’єднання (з’єднання) військ (сил) на суходолі, яка проводиться на приморському напрямку i $\epsilon$ 
загроза висадження морських i повітряних десантів противника на узбережжя для виходу у фланг або тил сухопутному угрупованню, що обороняється.

Метою протидесантної оборони є оборона прибережної смуги об'єднанням (з'єднанням) військ (сил), спільно з іншими складовими сил оборони, у взаємодії з ВМС, ПС ЗС України, для недопущення висадження морських і повітряних десантів противника з моря.

В основі протидесантної оборони $\epsilon$ загальні вимоги характерні для оборонної операції об'єднанням (з'єднанням) військ (сил) на суходолі. Проводиться протидесантна оборона у формі окремих боїв, а залежно від іiі масштабу - і бойових дій.

Прикладом в наших умовах $\epsilon$ підготовлена оборона оперативно-тактичного угруповання в районі Маріуполя, елементом якої $\epsilon$ протидесантна оборона морської ділянки узбережжя Азовського моря на випадок спроб російсько-окупаційних угруповань висадити тактичний морський чи повітряний десант.

Категорія третя: протидесантна операція - форма застосування оперативного (оперативно-тактичного) об'єднання (з'єднання) під час оборони морського узбережжя у випадку проведення противником морської десантної операції.

Протидесантна операція $\epsilon$ сукупністю узгоджених за цілями, завданнями, місцем i часом бойових дій об'єднання (з'єднання), які проводяться за єдиним замислом і планом у взаємодії з ВМС і ПС ЗС України за участі інших складових сил оборони.

Метою протидесантної операції $€$ відбиття ударів противника 3 моря, недопущення висадки його морських i повітряних десантів та утримання морського узбережжя.

Четверта категорія: берегова оборона полягає в обороні виділеними військовими частинами і підрозділами зі складу ЗС України, інших складових сил оборони важливих об'єктів на березі моря і в морі.

Метою проведення берегової оборони $€$ втримання важливих об'єктів державної i військової інфраструктури на березі моря і в морі від посягань агресора.

Слід наголосити, що у ЗС України берегова оборона як наукова категорія, так i фактично була відсутньою. Відтак, відсутність у нас берегової оборони дала змогу росіянам у березні 2014 року захопити і до сьогодні утримувати газодобувні вежі не тільки біля Криму, а й у виключній морській економічній зоні України у районі між Кримом (150 км) i Одесою (100 км).
3 огляду на наведені положення Доктрини слід визначитись 3 обороною морського узбережжя як різновидом оборони.

Щодо проведення силами оборони інформаційної, психологічної і кібернетичної операцій або дій.

Це питання має два основних аспекти. Acпект перший - у нашій державі не ведеться системна інформаційна діяльність. Інформаційна діяльність має проводитись у названих формах у масштабі держави в рамках стратегії (концепції) 3 інформаційної діяльності держави щодо забезпечення інформаційної безпеки.

Довідка. Згідно зі ст. 17 [10] “Захист суверенітету і територіальної цілісності України, забезпечення ii економічної та інформаційної безпеки $\epsilon$ найважливішими функціями держави, справою всього Українського народу".

Сили оборони, як і 3С України мають брати участь у цих формах інформаційної діяльності (операціях, акціях, заходах тощо). Тому не приходиться вести мову про ці операції у силах оборони чи ЗС України, які мають обмежені можливості з їх проведення і головне вони не узгоджені за єдиним замислом (концепцією) на рівні держави.

В інформаційній боротьбі (протидії) необхідно об'єднати і проводити за єдиним замислом (концепцісю) заходи 3 усіх ï трьох складових: інформаційної протидії негативному інформаційному впливу противника на особовий склад ЗС України i системи управління та інформаційний вплив на особовий склад i населення противника у формі спеціальної пропаганди; інформаційно-психологічний вплив на противника і захист від його деструктивного інформаційно-психологічного впливу i пропаганди; кіберзахист i кібервплив на противника.

Другий аспект - унаслідок неправильного розуміння сутності інформаційної діяльності щодо забезпечення інформаційної безпеки України, у нас вона штучно розділена на три форми: інформаційна, психологічна i кібернетична. Проведення заходів 3 вказаних споріднених форм розглядаються як різні галузі діяльності та покладаються на різні суб'єкти держави, що є помилкою.

Зрозуміло, що коли йдеться про інформаційну операцію то вона має інтегрувати дії різної спрямованості (власне інформаційної, інформаційно-психологічної, кібернетичної тощо) задля досягнення певної переваги над противником в інформаційному просторі та сприяння силам оборони в успішному виконанні завдань оборони держави.

Відтак, за результатами проведеного дослідження, пропонується окремо розглянути питання участі ЗС України i інших складових 
сил оборони в інформаційній діяльності держави iз забезпечення інформаційної безпеки України та належного забезпечення виконання завдань оборони.

Висновок. Як показало проведене дослідження, розроблення Доктрини застосування сил оборони держави $є$ кроком вперед у розвитку національного воєнного мистецтва і нині необхідно й надалі працювати над ii удосконаленням і розвитком, зокрема i 3 урахуванням наданого аналітичного матеріалу.

Доцільно підкреслити, що розробляти у подальшому ці та інші документи із застосування сил оборони, їх основної складової ЗС України необхідно з урахуванням положень законодавства України, воєнного мистецтва та відповідно до принципів і стандартів прийнятих в державах-членах НАТО.

\section{СПИСОК ВИКОРИСТАНОЇ ЛІТЕРАТУРИ}

1. Шамко В. Є., Жарик О. М., Коваль В. В. Розвиток форм i способів застосування Повітряних Сил Збройних Сил України в сучасних умовах ведення збройної боротьби. Наука і техніка Повітряних Сил Збройних Сил Украӥни. Харків, 2018. № 2 (31). С. 9-15.

2. Пелих А. О. Концепції застосування військової сили в системі державної політики національної безпеки CШA. URL: http://academy.gov.ua/ej/ej18/PDF/09.pdf

3. Пєвцов Г. В., Залкін С. В., Хударковський К. І., Феклістов А. О., Антонов А.В. Основні особливості ознак проведення інформаційнопсихологічної операції Російської Федерації в автономній республіці Крим. Наука $i$ техніка
Повітряних Сил Збройних Сил України. Харків, 2014. № 1 (14). C. 35-37.

4. Застосування Сухопутних військ Збройних Сил України у конфліктах сучасності : збірник тез доповідей науково-практичної конференції 14-15 листопада 2019 р. Львів : НАСВ, 2019. 308 с.

5. Про національну безпеку України : Закон України від 21.06 .2018 р. № 2469-VIII.

6. Воєнна доктрина України : Указ Президента України від 24.09.2015 р. №555/2015.

7. Про оборону України : Закон України від 06.12.1991 р. № 1932-XII. Відомості Верховної Ради України. 1992. № 9. Ст. 106.

8. Про Збройні Сили України : Закон України від 06.12.1991 № 1934-XII. Відомості Верховної Ради України. 1992. № 9. Ст. 108.

9. Про особливості державної політики із забезпечення державного суверенітету України на тимчасово окупованих територіях у Донецькій та Луганській областях : Закон України від 18.01.2018 № 2268-VIII. Відомості Верховної Ради Украйни. 2018. № 10. Ст. 54.

10. Конституція України : станом на 07 лютого 2019 р. / Верховна Рада України.

11. Сучасний тлумачний словник української мови / за заг. ред. В. В. Дубічинського. Харків : ВД “Школа”, 2009. $1008 \mathrm{c}$.

12. Про затвердження військово-адміністративного поділу території України : Указ Президента України від 05.02.2016 р. № 39/2016.

13. Про забезпечення прав i свобод громадян та правовий режим на тимчасово окупованій території України : Закон України від 27.04.2014 № 1207-VII. Відомості Верховної Ради України. 2014. № 26. Ст. 892. (Із змінами, внесеними згідно із Законами № 2581-VIII від 02.10.2018 р. Відомості Верховної Ради України. 2018. № 46. Ст. 371).

Стаття надійшла до редакційної колегії 15.01.2020

\section{Some aspects of the development of forms and methods of using the Armed Forces of Ukraine to repulse armed aggression in modern conditions}

\section{Annotation}

The protection of the National interests of Ukraine is the main task before the military-political leaders of the country. An important place in the defense of the country is the development of forms and methods of use of the Armed Forces to repel armed aggression in modern conditions. Contemporary military conflicts are increasingly gaining a "hybrid" character.

The purpose of the article is to present views on the development of forms and methods of use of the Armed Forces of Ukraine to repel armed aggression in the present conditions (based on the analysis of the domestic legislation, the governing documents of the Ministry of Defense of Ukraine, the Armed Forces of Ukraine, publications on the issue, the experience of conducting an anti-terrorist operation (Joint Operations) in the east of Ukraine).

In 2018, the Supreme Commander-in-Chief of the Armed Forces of Ukraine approved the Doctrine of Use of the State Defense Forces (hereinafter the Doctrine).

Scientific research has shown that the Doctrine in its essence, theoretical provisions, content is an important step forward in the further development of national martial arts. Undoubtedly that national military art in the face of Russian aggression needs its further and continuous development and improvement. The Doctrine mainly provides the forms and methods of use of troops (forces) of the Armed Forces of Ukraine, their peculiarities inherent in the conditions in Ukraine in connection with the armed aggression of the Russian Federation.

At the same time, the Doctrine contains provisions that contradict certain norms of domestic law, other normative legal acts and the theory of martial arts. Today it is necessary to continue to work on its improvement and development taking into account the available analytical material.

Keywords: doctrine; repulse of armed aggression against Ukraine; defense forces; Armed Forces of Ukraine and other components of the defense forces; joint forces; joint operation; operations of groupings of troops (forces). 